\title{
Religious Freedom of Members of Old and New Minorities: A Double Comparison
}

\author{
Fabienne Bretscher*
}

\begin{abstract}
Confronted with cases of restrictions of the right to manifest religious beliefs of new religious minorities formed by recent migration movements, the ECtHR and the UNHRC seem to opt for different interpretations and applications of this right, as recent conflicting decisions show. Based on an empirical legal analysis of the two bodies' decisions on individual complaints, this article finds that these conflicting decisions are part of a broader divergence: While the UNHRC functions as a protector of new minorities against States' undue interference in their right to manifest their religion, the ECtHR leaves it up to States how to deal with religious diversity brought by new minorities. In addition, a quantitative analysis of the relevant case law showed that the ECtHR is much less likely to find a violation of the right to freedom of religion in cases brought by new religious minorities as opposed to old religious minorities. Although this could be a hint towards double standards, a closer look at the examined case law reveals that the numerical differences can be explained by the ECtHR's weaker protection of religious manifestations in the public as opposed to the private sphere. Yet, this rule has an important exception: Conscientious objection to military service. By examining the development of the relevant case law, this article shows that this exception bases on a recent alteration of jurisprudence by the ECtHR and that there are similar prospects for change regarding other religious manifestations in the public sphere.
\end{abstract}

Keywords: ECtHR, UNHRC, religious manifestations, religious minorities, empirical analysis

\section{Introduction}

Since several years now, religious intolerance has been on the rise. ${ }^{1}$ In particular the so-called new religious minorities originating from recent migration movements, such as Sikhs or Muslims in some European States, seem to encounter growing opposition to practicing their religions. One example is the increasing hostility against Muslims, which led States to prohibit the

\section{PhD candidate at the University of Zurich}

1. See already UN Commission on Human Rights Res. 1986/20, 10 March 1986, which appointed a Special Rapporteur on Religious Intolerance. In 2000, the mandate title was changed to Special Rapporteur on Freedom of Religion or Belief. construction of minarets ${ }^{2}$ or the wearing of headscarves in public schools. ${ }^{3}$ The question thus arises whether the guarantees of religious freedom enshrined in international human rights instruments like the International Covenant on Civil and Political Right (hereinafter ICCPR $)^{4}$ or the European Convention of Human Rights (hereinafter ECHR) are able to deal with this challenge and ensure that everybody can enjoy freedom of religion equally, 'without distinction of any kind'.

The respective supervisory bodies, namely the United Nations Human Rights Committee (hereinafter UNHRC) and the European Court of Human Rights (hereinafter ECtHR), are responsible for adapting international human rights norms to the needs of today. By applying and interpreting the abstract human rights guarantees, such as the right to freedom of religion, in specific cases or situations these supervisory bodies continuously shape and develop the understanding of human rights. ${ }^{6}$ When it comes to new religious minorities' right to manifest their religious beliefs, diverging interpretations by international human rights bodies can be found. As an example, the complaints brought to the ECtHR as well as the UNHRC based on a French law prohibiting religious symbols or clothing in public schools 'by means of which students manifest their religious belonging in an ostentatious way" can be mentioned. Based on this law, several Muslim and Sikh students were excluded from public schools because they did not refrain from wearing a headscarf or a turban. While the ECtHR declared all complaints manifestly illfounded and thus inadmissible, ${ }^{8}$ the UNHRC found a

2. See Art. 72(3) of the Swiss Constitution, introduced in the popular vote of 29 November 2009.

3. Law no. 2004-228, 15 March 2004, available at: <https://www. legifrance.gouv.fr/affichTexte.do?cidTexte=JORFTEXT000000417977\& categorieLien $=\mathrm{id}>$.

4. 16 December 1966, 999 UNTS 171.

5. Art. 2 of the Universal Declaration of Human Rights, 10 December 1948 UNGA Res 217 A (III) (hereinafter UDHR).

6. C. Medina, 'The Role of International Tribunals: Law-Making or Creative Interpretation?', in D. Shelton (ed.), The Oxford Handbook of International Human Rights Law (2013) 649, at 651.

7. Law no. 2004-228 (above n. 3); Original wording: '[P]ar lesquels les élèves manifestent ostensiblement une appartenance religieuse'.

8. Aktas v. France, App. no. 43563/08 (ECHR, 30 June 2009); Bayrak v. France, App. no. 14308/08 (ECHR, 30 June 2009); Gamaleddyn v. France, App. no. 18527/08 (ECHR, 30 June 2009); Ghazal v. France, App. no. 29134/08 (ECHR, 30 June 2009); Jasvir Singh v. France, App. no. 25463/08 (ECHR, 30 June 2009); Ranjit Singh v. France, App. no. 27561/08 (ECHR, 30 June 2009). 
violation of the students' right to manifest their religion. $^{9}$

Confronted with such apparent divergence, the present article seeks to answer the following two questions, which are based on a double comparison: Are the mentioned conflicting decisions of the UNHRC and the ECtHR part of a broader divergence in the interpretation and application of new religious minorities' right to manifest their religion? Does the ECtHR adopt an equally restrictive approach towards both old and new religious minorities or can double standards in the ECtHR's jurisprudence be identified?

\section{Methodological Remarks}

When looking at the existing scholarship on freedom of religion in international human rights law, a lack of empirical legal research ${ }^{10}$ can be identified. Differently than other scholarly work in this field, this article thus puts forward a systematic analysis of the decisions and recommendations taken in cases relating to religious minorities' right to manifest their religion brought under the individual complaint mechanisms of the ECtHR and the UNHRC. Taking a holistic approach to the topic of minorities' religious freedom, this research not only includes decisions regarding the mentioned new religious minorities, which have been present on the territory of the State in question for a comparatively short period of time, but also examines the interpretation and application of old religious minorities' right to manifest their religious beliefs. Such groups are characterised by the long ties with the territory they inhabit. ${ }^{11}$ In order to interpret the findings of this empirical research of the practice of the ECtHR (and the now obsolete European Commission of Human Rights (hereinafter EComHR)) as well as the UNHRC in the context of individual applications, which are presented in the third and fourth section, it is important to first clarify the methodology. After raising some caveats for the comparison of the practice of the supervisory bodies of the ECHR and the ICCPR as well as a more meticulous definition of the concepts of old and new religious minorities, this section thus presents the detailed research design used by this article.

\subsection{Caveats for the Comparison of the ECtHR and the UNHRC}

The analysis put forward by this article takes into account that the two bodies, the ECtHR and the UNHRC, are operating in very different contexts:

9. UNHRC Bikramiit Singh v. France, UN Doc. CCPR/C/106/D/ 1852/2008 (1 November 2012)

10. According to the definition adopted by this article, empirical research 'involves the systematic collection of information ("data") and its analysis according to some generally accepted methods' ( $\mathrm{P}$. Cane and $\mathrm{H}$. Kritzer, 'Introduction', in P. Cane and H. Kritzer (eds.), The Oxford Handbook of Empirical Legal Research (2010) 1, at 4).

11. See, for further elaborations on the distinction of old and new religious minorities, Section 2.2
While the Council of Europe (CoE) is characterised by the relatively homogenous legal and democratic systems in Europe, the United Nations (UN) combine a 'vast range of ideological, religious and cultural foundations $^{12}$ of government systems. Moreover, there are also significant institutional differences between the two supervisory bodies. The ECtHR, on the one hand, is today a permanent body with one judge for every $\mathrm{CoE}$ Member State. ${ }^{13}$ The UNHRC on the other hand is a non-permanent body of independent experts, whose eighteen members meet three times a year for three weeks. ${ }^{14} \mathrm{~A}$ further institutional difference between the two bodies lies in the fact that while the ECtHR's main function is the adjudication of individual applications, ${ }^{15}$ the UNHRC's main task is the examination of State reports. ${ }^{16}$ The UNHRC's competence to consider individual complaints is not included in the ICCPR, but States can accept the jurisdiction of the UNHRC by ratifying a separate Protocol to the ICCPR ${ }^{17}$ For Signatories of the ECHR, the acceptance of the ECtHR's jurisdiction, however, is mandatory.

The last and maybe most crucial difference is the bindingness of their decisions for Member States. While the ECtHR's judgments and decisions have binding force for the Signatories, the UNHRC can only issue recommendations, which are nevertheless of real legal significance. ${ }^{18}$ With the interpretation and application of relevant human rights guarantees, the UNHRC contributes to specifying States' human rights obligations and thus shapes expectations towards States' behaviour. ${ }^{19}$

Despite these differences, the idea of a comparison of the application and interpretation of freedom of religion in the context of individual complaints to the ECtHR and the UNHRC seems compelling because the two bodies interpret provisions with a very similar wording. ${ }^{20}$ In particular the general guarantee of religious freedom in Articles 9(1) ECHR and 18(1) ICCPR as well as the limitation clauses in Section 2 of the respective provisions were drafted in a nearly identical way. Both provisions are furthermore historically interrelated as Article 18 UDHR strongly influenced both. In fact, the intention of the drafters was to base Article 9 ECHR 'as far as possible on the UDHR in order to reduce the risk of devising definitions that were at odds with those in UN instruments' ${ }^{21}$ Thus, it is interesting to examine how the different systems developed the interpretation and application of this human right in the

12. P. Taylor, Freedom of Religion - UN and European Human Rights Law and Practice (2005), at 4.

13. Arts. 19 and $20 \mathrm{ECHR}$.

14. Art. 37 ICCPR.

15. Art. $34 \mathrm{ECHR}$.

16. Art. 40 ICCPR.

17. First Additional Protocol to the ICCPR, 16 December 1966, 999 UNTS 171.

18. Art. 46 ECHR; Art. 5 First Additional Protocol to the ICCPR; N. Rodley, 'The Role and Impact of Treaty Bodies', in Shelton (ed.), above n. 6, at 639.

19. Rodley, above n. 18, at 639.

20. For an earlier comparison of the two bodies, see Taylor, above n. 12

21. Ibid., at 7; for further details see C. Evans, Freedom of Religion under the European Convention on Human Rights (2001), at $33 \mathrm{ff}$. 
course of their numerous years of activity and how they are coping with the challenges posed to the right to manifest religious beliefs today. ${ }^{22}$

\subsection{Defining the Concepts: Old and New Religious Minorities}

The basic conceptual distinction of the present research is between two groups, namely old religious minorities and new religious minorities originating from migration. When trying to develop a definition of these two concepts, it needs to be noted that the definition of the term minority has been subject to controversy for many years now and no legally binding definition could be found on the international level. ${ }^{23}$ At first, scholars and international bodies opted for a restrictive definition of the term 'minority', including only groups consisting of citizens of the State in question and/or having historical, long-standing ties with the territory they inhabit. ${ }^{24}$ While States, such as Norway and Switzerland, still argue that only so-called old or traditional minorities should be included in the definition of the term 'minority', 25 the general consensus today tends towards a definition encompassing also 'new minorities' formed by recent migration, who have thus lived on the territory for a comparatively short period of time. Consequently, a significant part of scholarship as well as international bodies, for example the UNHRC, argue that the term 'minority' is not limited to a fixed set of groups, but rather evolving with time. ${ }^{26}$

22. This article focuses on general human rights guarantees, which play a significant role in modern international minority protection; see UN Economic and Social Council, 'Prevention of Discrimination and Protection of Minorities', Progress report on the update to the study on peaceful and constructive approaches to situations involving minorities submitted by A. Eide, UN Doc. E/CN.4/Sub.2/2003/21, 17 June 2003, at para. 40.

23. For an overview of the discussions and attempts, see K. Henrard, Devising an Adequate System of Minority Protection (2000), at $18 \mathrm{ff}$.

24. See, for example, the definition put forward by Francesco Capotorti, Special Rapporteur of the United Nations Sub-Commission on Prevention of Discrimination and Protection of Minorities: 'A group numerically inferior to the rest of the population of a state, in a non-dominant position, whose members - being nationals of the state - possess ethnic, religious or linguistic characteristics differing from those of the rest of the population and show, if only implicitly, a sense of solidarity, directed towards preserving their culture, traditions, religion or language.' ('Study on the Rights of Persons Belonging to Ethnic, Religious and Linguistic Minorities', UN Doc. E/CN.4/Sub.2/384, 20 June 1977).

25. See, for example, Council of Europe, Reservations and Declarations for Treaty No. 157 - Framework Convention for the Protection of National Minorities, <www.coe.int/en/web/conventions/full-list/-/conventions/ treaty/157/declarations?p_auth=2RpNP29s> (last visited 20 February 2017), in particular the declarations of Armenia, Germany, Georgia, Austria, Moldavia, Czech Republic, Switzerland and Norway.

26. See, for example, European Commission for Democracy Through Law (Venice Commission), Report on Non-Citizens and Minority Rights, CDL-AD(2007)001, 18 January 2007; A. Eide, 'The Rights of "New" Minorities: Scope and Restrictions', in K. Henrard (ed.), Double Standards in Minority Protection (2010), at 165; R. Medda-Windischer, Old and New Minorities: Reconciling Diversity and Cohesion - A Human Rights Model for Minority Integration (2009); K. Henrard, 'Minority Specific Rights: A Protection of Religious Minorities Going Beyond the Freedom of Religion?', 8(5) European Yearbook of Minority 5, at 7 (2009); J. Ringelheim, 'Minority Rights in a Time of Multiculturalism The Evolving Scope of the Framework Convention on the Protection of National Minorities', 10(1) Human Rights Law Review 99, at $110 \mathrm{ff}$. (2010).
An exhaustive presentation of the different arguments brought forward in the controversy surrounding the definition of the term 'minority' would go beyond the scope, and purpose, of this article. It shall thus suffice to highlight that discussions on the rights of both old and new minorities, independently of the terminology used, can be seen as forming part of the broader question of how and whether the separate identity of groups, which are religiously, but also ethnically, culturally or linguistically, diverse from the dominant population, should be protected. Considering that the aim of this article is in fact to compare the protection of such minority groups' religious freedom by two international human rights bodies, the terminology of old and new minorities fits this purpose best.

Though, in the context of religious minorities, it needs to be clarified that this article does not aim at so-called 'new religious movements', for example Scientology, but rather focuses on new religious minorities, which were formed because of recent migration movements, but adhere to traditional religions. The emphasis lies thus on the link of new religious minorities with migration, as this is also highlighted by the scholars using the terminology. ${ }^{27}$ In this context the term 'new minority' is used to emphasise the fact that children, whose parents or grandparents immigrated to a certain country, cannot be included in the term migrants, as they have in fact not migrated themselves. ${ }^{28}$ Instead they should be called new minorities, who are distinguished from old minorities by means of the criteria of the time they are present on the territory of the State in question. Whether a specific group can be qualified as a new or old religious minority depends thus on its demographic development in a certain State, which makes the distinction used by the article, like the definition of the term minority in general, inherently relative. ${ }^{29}$ Thus, the categorisation of specific groups has to be determined on a case-bycase basis.

Based on this distinction, specific groups have been selected, which allows us to draw representative results from the empirical legal research, while at the same time respecting the inherent limitations of this article. Thus, out of the applicants alleging a violation of their right to freedom of religion in a complaint to the UNHRC or the ECtHR, only groups that have brought at least one complaint to both the UNHRC and the ECtHR were included, as otherwise a comparison of the two approaches would be impossible.

Accordingly, the category nem religious minority includes only cases brought by persons adhering to the Sikh and Muslim faith. In the countries, against which the included cases were directed, these groups represent members of groups formed by recent migration movements, which have lived on the territory for a comparatively short time. As an example, Muslims, who have emigra-

\footnotetext{
27. See, for example, Medda-Windischer, above n. 26, at $40 \mathrm{ff}$.

28. See also ibid., at 51

29. See P. Vuciri Ramaga, 'Relativity of the Minority Concept', 14(1) Human Rights Quarterly 104 (1992).
} 
ted for example from Turkey to Germany, but also their children and grandchildren, can be mentioned. For the category old religious minority, these are members of Jewish and Muslim ${ }^{30}$ communities as well as Jehovah's Witnesses and Baptists. These groups categorised as old minorities can be seen as having long-standing ties with the territory or State they inhabit. ${ }^{31}$ The Baptist Church for example was established already in $1609^{32}$ and Jehovah's Witnesses' origins can be traced back to the 19th century. ${ }^{33}$

\subsection{Data Collection ${ }^{34}$}

For the EComHR and the ECtHR, the data used for conducting the empirical research was collected using the hudoc jurisprudence database. ${ }^{35}$ All judgments on the merits and decisions on the admissibility, in which the applicant had alleged a violation of Article 9 ECHR, were included in the search. This does not necessarily entail that the ECtHR (respectively the EComHR) dealt with the case under Article 9 ECHR. ${ }^{36}$ This search yielded 1,403 results as of 31 December 2016. Subsequently, a range of restrictions were applied to this set of data:

- Cases where the claimant had brought forward Article 9 ECHR, but which in fact did not raise any question under this guarantee, were excluded.

- Complaints declared inadmissible based on Article 35 ECHR were in general excluded from the collection, except for complaints that were declared inadmissible as they were manifestly ill-founded, because such decision involves often an assessment of the merits of the case. ${ }^{37}$

- The cases were limited according to the above-specified definition of old and new religious minorities to complaints brought forward by persons or associations belonging to these two categories.

- Complaints brought forward by religious associations or communities regarding legal recognition were excluded, as the focus of this article lies on the possibility of the individual to enjoy the right to freedom of religion. ${ }^{38}$

30. Depending on their historical development in the State in question, Muslims can be both an old and a new minority.

31. For the community of Jehovah's Witnesses in Austria, see Religionsgemeinschaft der Zeugen Jehovas and others v. Austria, App. no. 40825/98 (ECHR, 31 July 2008), at para. 98.

32. R. Johnson, A Global Introduction to Baptist Churches (2010), at XVI $\mathrm{ff}$.

33. G. Chryssides, Jehovah's Witnesses - Continuity and Change (2016), at $25 \mathrm{ff}$.

34. The design of the empirical research is based on the guidelines for empirical legal research as presented by L. Epstein and A. Martin, 'Quantitative Approaches to Empirical Legal Research' in Cane and Kritzer (eds.), above n. 10, at 901; L. Webley, 'Qualitative Approaches to Empirical Legal Research', in Cane and Kritzer (eds.), above n. 10, at 926.

35. Available at: <http://hudoc.echr.coe.int>

36. See, for example, Tsirlis and Kouloumpas v. Greece, ECHR 1997-III 1.

37. See, for example, ECtHR Aktas v. France, above n. 8

38. Although it is acknowledged that such legal recognition can have significant consequences for the religious freedom of individual members of such communities, considering all relevant decisions would go beyond the scope of the present article.
This led to a final sample of seventy-two cases ${ }^{39}$ for the ECtHR.

The same approach was adopted for the case law of the UNHRC, collected via the UN jurisprudence database. ${ }^{40}$ The search of the jurisprudence of the UNHRC based on Article 18 ICCPR yielded 51 results as of 31 December 2016, which were then limited as well according to the above-specified criteria to a final sample of seventeen cases for the UNHRC.

Compared to the seventy-two cases brought to the ECtHR, this amount seems rather small. In this regard, it should be noted that among the various UN human rights bodies, the UNHRC has dealt with individual complaints for the longest and its case law is the most comprehensive and developed. ${ }^{41}$ Moreover, there is no special UN human rights treaty on the freedom of religion or on the rights of minorities. ${ }^{42}$ Nevertheless, the UNHRC has received significantly fewer complaints than the ECtHR from religious minorities. Though, despite the difference in numbers between the two bodies' practice, the empirical research can lead to indicative results as the seventeen cases represent the cases, which are relevant to the topic of the article and could be found based on the above-specified method of data collection. ${ }^{43}$ Consequently, based on these seventeen cases, general conclusions can be drawn regarding the approach towards old and new religious minorities' right to freedom of religion adopted by the UNHRC.

\section{Divergence in the Protection of New Minorities' Right to Freedom of Religion}

After having presented the design of the empirical legal research, which lies at the heart of this article's inquiry, this section analyses the first comparative question posed, namely whether the conflicting decisions of the UNHRC and the ECtHR, which can be found regarding the French Loi Stasi, ${ }^{44}$ reflect a broader tendency for divergence in the interpretation and application of

39. It is important to highlight that this research in general takes a casebased approach, that means that the numbers refer to 'the collection of facts on a particular series of events and relevant legal material, leading to a formal legal decision by the Court' (S. Altwicker-Hàmori, T. Altwicker \& A. Peters, 'Measuring Violations of Human Rights - An Empirical Analysis of Awards in Respect of Non-Pecuniary Damage under the European Convention on Human Rights', 76(1) Zeitschrift für ausländisches öffentliches Recht und Völkerrecht 1, at 24 (2016)).

40. Available at: <http://juris.ohchr.org/search/Documents>

41. Rodley, above n. 18, at 634

42. See, however, the UNGA 'Declaration on the Elimination of All Forms of Intolerance and of Discrimination Based on Religion or Belief', UN Doc. A/RES/36/55, 25 November 1981; UNGA 'Declaration on the Rights of Persons Belonging to National or Ethnic, Religious and Linguistic Minorities', UN Doc. A/RES/47/135, 18 December 1992; UNGA 'Declaration on the Rights of Indigenous Peoples', UN Doc. A/RES/61/295, 2 October 2007.

43. See M.A. Hall and R.F. Wright, 'Systematic Content Analysis of Judicial Opinions', 96(1) California Law Review 63, at $101 \mathrm{ff}$ (2008).

44. See Section 1. 
Table 1 Percentages of violations, no violations and inadmissibility decisions of the UNHRC and the ECtHR regarding nem religious minorities

\begin{tabular}{|l|l|l|l|l|l|l|}
\cline { 2 - 4 } \multicolumn{2}{c|}{} & \multicolumn{2}{l|}{ UNHRC } & \multicolumn{2}{l|}{ ECtHR } \\
\hline Decision & Viol. & No viol. & Inadm. & Viol. & No viol. & Inadm. \\
\hline Sikhs & $75 \%$ & $25 \%$ & $0 \%$ & $0 \%$ & $0 \%$ & $100 \%$ \\
\hline Muslims & $0 \%$ & $0 \%$ & $100 \%$ & $0 \%$ & $26.7 \%$ & $73.3 \%$ \\
\hline Total & $60 \%$ & $20 \%$ & $20 \%$ & $0 \%$ & $18.2 \%$ & $81.8 \%$ \\
\hline
\end{tabular}

new religious minorities' right to freedom of religion by the two bodies. The present section seeks to answer such question first based on a quantitative analysis of the cases selected for the empirical analysis, which introduces the key points of the divergence between the two bodies' case law. By means of an in-depth analysis of the reasoning applied in certain factually comparable cases, a second part of this section then highlights that the interpretation and application of new minorities' right to manifest their religious beliefs by the UNHRC and the ECtHR are diverging.

\subsection{The Two Bodies' Practice in Numbers}

Out of the final sample of eighty-nine cases, twenty-seven concerned groups belong to the category nem religious minority according to the above-specified definition. A quantitative comparison of the practice of the ECtHR with that of the UNHRC relating to complaints brought by new religious minorities according to the limited scope put forward above, namely Sikhs and Muslims, allows us to observe significant differences in the percentage of violations found and complaints declared inadmissible.

The UNHRC has received five complaints by new religious minorities alleging a violation of their right to manifest their religion. In three of these complaints, all brought by Sikhs, that is 60 per cent of all cases, the State was found to have violated Article 18 ICCPR. In one case, also brought by a Sikh, no violation was found (20 per cent) and one complaint brought by a Muslim was declared inadmissible (20 per cent).

By contrast, the ECtHR or the now obsolete EComHR have received twenty-two complaints from Muslim and Sikh new minorities and did not consider any of these complaints a violation of Article 9 ECHR. Only in four cases, that is 18 per cent, the ECtHR examined the merits of the case, but found no violation. More than 80 per cent, that is eighteen cases, were not examined on the merits, but declared manifestly ill-founded and thus inadmissible. This might hint towards a much more restrictive interpretation of new minorities' right to manifest their religious beliefs compared to the UNHRC, where 60 per cent of the cases were found to amount to a violation (Table 1 ).

The most salient in the results of this empirical legal analysis might be that for thirty years, namely from 1978, when the first relevant complaint was brought to the EComHR, ${ }^{45}$ until $2008,{ }^{46}$ all complaints of new religious minorities had been declared inadmissible. Also, following these two decisions in 2008, only two more cases have been examined on their merits, one of them by the Grand Chamber. ${ }^{47}$

\subsection{A Look behind the Numbers}

The most striking difference perceivable from the quantitative comparison of the two bodies' practice appears to be the fact that the ECtHR did not find any violation of the right to manifest their religion of a member of a new minority, while the UNHRC found three despite being confronted with a much smaller number of claims. Nevertheless, these numerical differences alone are not sufficient evidence to conclude that there is a divergence in the international protection of new minorities' right to manifest their religious beliefs, as law does not operate according to mathematical rules. Consequently, it is necessary to examine whether any of the cases, in which the UNHRC found a violation of Article 18 ICCPR, was based on similar facts as the cases in which the ECtHR did not find a violation or which were declared inadmissible.

All three decisions, in which the UNHRC found a violation, concern members of the Sikh community in France. Two cases concern the practice of French authorities to require the removal of religious symbols such as turbans and headscarves for official photographs. In the case Ranjit Singh v. France ${ }^{48}$ regarding the requirement to appear bareheaded on the photo for the residence permit, the UNHRC decided that France had not given reasons for how this requirement would contribute to ensuring public safety. Furthermore, it did not see how this would facilitate the identification of the applicant or lower the risk for fraud or falsification of the residence permit. It denied thus the proportionality of the interference with Mr. Singh's right to manifest his religion. The same reasoning was applied to the second case, Shingara Mann Singh v. France, ${ }^{49}$ in which the applicant was required to provide a photo without a tur-

45. X. v. the United Kingdom (1978), DR 14, 234

46. See Dogru v. France, App. no. 27058/05 (ECHR, 4 December 2008) as well as Kervanci v. France, App. no. 31645/04 (ECHR, 4 December 2008).

47. See S.A.S. v. France [GC], ECHR 2014-III 291 (extracts); Ebrahimian v. France, ECHR 2015.

48. UNHRC Ranjit Singh v. France, UN Doc. CCPR/C/102/D/1876/2009, 27 September 2011

49. UNHRC Shingara Mann Singh v. France, UN Doc. CCPR/C/108/D/ 1928/2010, 26 September 2013. 
ban for his passport, when he renewed it for the fifth time.

Interestingly, the same applicant had brought a complaint to the ECtHR five years earlier, ${ }^{50}$ alleging that the refusal of French authorities to renew his drivers' licence, because he did not provide a photo without the turban, violated Article 9 ECHR. ${ }^{51}$ The ECtHR had declared his complaint manifestly ill-founded and thus inadmissible. Without examining the case in depth, the Court supported the reasoning brought forward by France that the bareheaded photograph was necessary for the identification of the applicant and to prevent fraud or falsification. ${ }^{52}$

It seems thus that the UNHRC consciously adopted a decision, which directly contradicted the decision taken by the ECtHR some years earlier. ${ }^{53}$ Although France had invoked the decision taken by the ECtHR in this regard, ${ }^{54}$ the UNHRC did not mention it at all in its own elaborations on the merits of the case. The same can be observed in the set of cases ${ }^{55}$ mentioned in the introduction of this article, namely regarding the French Loi Stasi, ${ }^{56}$ prohibiting ostentatious religious symbols or clothing in public schools. This law can be set in the context of the implementation of the French constitutional principle of laïcité ${ }^{57}$ which is defined primarily by the non-religious nature of the French Republic and public service. ${ }^{58}$ Such religious neutrality towards all religions shall guarantee freedom of belief and conscience. ${ }^{59}$ Also here, the decisions of the ECtHR had been taken some years before the UNHRC decided

50. See, for an analysis of the relationship of the UNHRC and the ECtHR regarding cases where the same or a similar complaint is brought to both bodies, C. Phuong, 'The Relationship Between the European Court of Human Rights and the Human Rights Committee: Has the "Same Matter" Already Been "Examined"?', 7(2) Human Rights Law Review 385 (2007).

51. Mann Singh v. France, App. no. 24479/07 (ECHR, 13 November 2008).

52. This approach might also be connected with general obscurities with regard to the proportionality test applied by the ECtHR; see E. Brems and L. Lavrysen, "“Don't Use a Sledgehammer to Crack a Nut": Less Restrictive Means in the Case-law of the European Court of Human Rights', 2015 Human Rights Law Review 1; J. Kratochvíl, 'The Inflation of the Margin of Appreciation by the European Court of Human Rights', 29 Netherlands Quarterly of Human Rights 324 (2011).

53. See, for another example, UNHRC Maria Cruz Achabal Puertas v. Spain, UN Doc. CCPR/C/107/D/1945/2010, 27 March 2013, discussed by J. Gerards, 'Inadmissibility Decisions of the European Court of Human Rights: A Critique of the Lack of Reasoning', 14 Human Rights Law Review 148 (2014)

54. See UNHRC Ranjit Singh v. France, above n. 48, at para. 5.2.

55. UNHRC Bikramiit Singh v. France, above n. 9; ECtHR Jasvir Singh v. France, above n. 8; ECtHR Ranjit Singh v. France, above n. 8; ECtHR Aktas v. France, above n. 8; ECtHR Bayrak v. France, above n. 8; ECtHR Gamaleddyn v. France, above n. 8.

56. Law no. 2004-228, above n. 3

57. See W. de Been, 'The Quest of Neutrality and the Stench of History', in J. Temperman (ed.), The Lautsi Papers: Reflections on Religious Symbols in the Public School Classroom (2012) 177, at 184; for an in-depth analysis see E. Bribosia, G. Caceres \& I. Rorive, 'Les Signes Religieux au Coeur d'un Bras de Fer entre Genève et Paris: La Saga Singh', 98 Revue Trimestrielle des Droits de l'Homme 495 (2014).

58. P.-H. Prélot, 'Définir Juridiquement la Laïcité', in G. Gonzalez (ed.), Laïcité, Liberté de Religion et Convention Européenne des Droits de I'Homme: Actes du Colloque le 18 Novembre 2005 (2006) 115, at 117.

59. Ibid on the complaint; the latter, however, again did not follow the ECtHR's decisions on the same matter.

Apart from these two examples of the UNHRC's conscious contradiction of the ECtHR's approach, the divergence in the approach of the two human rights bodies can also be detected in the rest of their case law regarding new religious minorities' right to manifest their religious beliefs. A detailed comparison clearly shows that the two bodies interpret the permitted limitations to the right to manifest religious beliefs embedded in the ECHR and the ICCPR and their task in its protection very differently. While the UNHRC opts for an in-depth and concrete verification of the arguments brought forward by both parties and thus applies strict scrutiny, the ECtHR in all cases decided to leave the national authorities a wide margin of appreciation. ${ }^{60}$ The ECtHR generally does not scrutinise the arguments brought forward by the State, ${ }^{61}$ the UNHRC on the other hand examines whether the justification put forward for the interference with the respective applicant's right to freedom of religion holds true in the concrete case. Hence, the ECtHR does not seem very keen on touching on the issue of religious diversity brought by new religious minorities, leaving it up to Member States how to deal with the issue. ${ }^{62}$ By contrast, the UNHRC acts as a protector of new religious minorities against undue interference in their right to manifest their religion by States.

This does not necessarily mean that for the UNHRC, every restriction amounts to a violation, as the admittedly not very recent case Karnel Singh Binder v. Canada ${ }^{63}$ exemplifies. The case concerned a person adhering to the Sikh faith who worked as an electrician for the Canadian National Railway Company. When a hardhat requirement was introduced, $\mathrm{Mr}$ Singh Binder, who was wearing a turban for religious reasons, was offered a transfer to another post, which he refused. His employ-

60. See also Bribosia et al., above n. 57, at $495 \mathrm{ff}$. It should be noted here that in recent years Member States have significantly criticised the ECtHR, which has created a strong movement towards more deference to national instances. As a consequence, the principle of subsidiarity and the doctrine of the margin of appreciation, which have been used by the ECtHR to grant deference to Member States, are to be introduced to the preamble of the ECHR by the Additional Protocol No. 15, which has not yet entered into force. The Court's strong reliance on the margin of appreciation may thus very likely be linked to such movement, which is however not the focus of this article. For a more detailed account of the concept of margin of appreciation and its use by the ECtHR, see Kratochvíl, above n. 52.

61. As was highlighted many times, the granting of the margin of appreciation by the ECtHR goes hand in hand with restricted scrutiny: see, for example, K. Henrard, 'A Critical Analysis of the Margin of Appreciation Doctrine of the ECtHR, with Special Attention to Rights of a Traditional Way of Life and a Healthy Environment: A Call for an Alternative Model of International Supervision', IV The Yearbook of Polar Law 365, at 366 ff. (2012).

62. This approach can be based on a variety of reasons, but has been convincingly shown to be linked to how controversially an issue is discussed (see K. Henrard, 'Duties of Reasonable Accommodation on Grounds of Religion in the Jurisprudence of the European Court of Human Rights: A Tale of (Baby) Steps Forward and Missed Opportunities', 14(4) International Journal of Constitutional Law 961, in particular at 983 (2016)).

63. UNHRC Karnel Singh Binder v. Canada, UN Doc CCPR/C/37/D/ 208/1986, 9 November 1989 
ment was then terminated. The UNHRC found no violation of the applicant's freedom of religion as it saw the requirement to protect workers from injury and electric shocks as reasonable and directed towards objective purposes. ${ }^{64}$ This approach is similar to the EComHR's in a case regarding the mandatory wearing of crash helmets on motorcycles. ${ }^{65}$ Although it is unclear whether the UNHRC would adopt the same approach today as it has more than twenty-five years ago, one important difference certainly remains the same: The EComHR declared the complaint manifestly ill-founded and did thus not examine the merits of the case. ${ }^{66}$

Considering the fact that more than 80 per cent of the analysed complaints brought by new religious minorities to the ECtHR and the EComHR were declared inadmissible, this could be suggestive of a more general issue: It seems that the ECtHR does not want to interfere with States' approaches to dealing with religious diversity, which is a very controversial issue today. In the clear majority of the cases, this means that the complaint is not even examined on the merits, but it is declared that the allegations of a violation of the right to manifest religious beliefs lack any foundation. By declaring such a large amount of complaints brought by new religious minorities inadmissible, the ECtHR thus refuses to participate in the manifold discussions on the human rights conformity of such restrictions of new minorities' religious freedom and negates basic principles of procedural justice to new religious minorities. ${ }^{67}$

Thus, the question arises whether this is a general approach taken by the ECtHR in the context of religious groups facing difficulties in realising their right to manifest their religion, or whether this is only the case for new religious minorities. If the latter would hold true, this would not only indicate divergence between the UNHRC and the ECtHR, but also double standards from the side of the ECtHR to new minorities' complaints alleging a violation of their right to manifest their religious beliefs. ${ }^{68}$

\section{Double Standards in the Protection of Old and New Religious Minorities?}

This section seeks to reflect on the second comparative question posed by this article, namely whether, apart

64. For a critical account of this recommendation, see S. Joseph and $M$. Castan, The International Covenant on Civil and Political Rights: Cases, Materials, and Commentary (2013), at 574.

65. See ECtHR X. v. the United Kingdom, above n. 45 .

66. See also the article of Gerards, above n. 53, highlighting the same issue for a different set of cases.

67. See also E. Brems and L. Lavrysen, 'Procedural Justice in Human Rights Adjudication: The European Court of Human Rights', 35(1) Human Rights Quarterly 176, at 186 (2013)

68. This article recognises that there are many different factors influencing the line a particular judicial body choses, and focuses however on the distinction between old and new minorities as one potential factor. from interpreting and applying the right to manifest religious beliefs in the context of claims of new religious minorities more restrictively than the UNHRC, the ECtHR also follows a different approach for old than for new religious minorities. In order to do so, the same quantitative analytical methods as for the case law regarding new religious minorities was applied to complaints brought by old religious minorities. ${ }^{69}$ The results of this analysis show that the ECtHR is more likely to find a violation of the right to manifest religious beliefs of old religious minorities than of new religious minorities. Subsequently, an attempt to justify the numerical differences found is made, to determine whether the ECtHR's approach to new religious minorities' claims is based on double standards or can rather be explained based on factual differences of the cases.

\subsection{A Quantitative Perspective on the Relevant Practice}

Out of the fifty decisions the ECtHR and the EComHR issued with regard to old religious minorities, thirty, that is 60 per cent, found a violation of the right to freedom of religion. In seven cases, that is 14 per cent, no violation was found. Thirteen complaints, which amount to 26 per cent, were declared manifestly illfounded and thus inadmissible. When comparing these abstract percentages to the ones for new religious minorities' complaints, it is striking that here, a reverse trend is observable: For new minorities, no complaint was seen to amount to a violation of Article 9 ECHR, while for old religious minorities over half of the decisions, namely 60 per cent, found a violation. Furthermore, only 26 per cent of old religious minorities' complaints were declared inadmissible while for new minorities this amounted to more than 80 per cent (Figure 1).

For the UNHRC, such reverse trend cannot be observed: In all twelve cases brought by old religious minorities, the UNRHC found a violation. Although this is a higher percentage than for new religious minorities, where 60 per cent of the recommendations found a violation, the differences do not appear very significant, in particular when taking into account that the sample for new minorities only includes five cases.

Thus, the question arises: Are we confronted with double standards in the case law of the ECtHR? Taking a closer look at the four groups hidden behind the seemingly obvious double standards in the ECtHR's case law, one gets a mixed impression: Most complaints were brought by Jehovah's Witnesses, of which a very high number of cases, namely 71.4 per cent, were seen as amounting to a violation. Surprisingly, the largest percentage of violations was found for complaints brought by old Muslim minorities, namely 80 per cent. Only in one case no violation was found and one complaint was declared inadmissible. By contrast, for complaints brought by new Muslim minorities not one violation

Due to the reasons specified in Section 2.2, groups included in the definition of old minorities were restricted to Jews, Muslims, Jehovah's Witnesses and Baptists. 


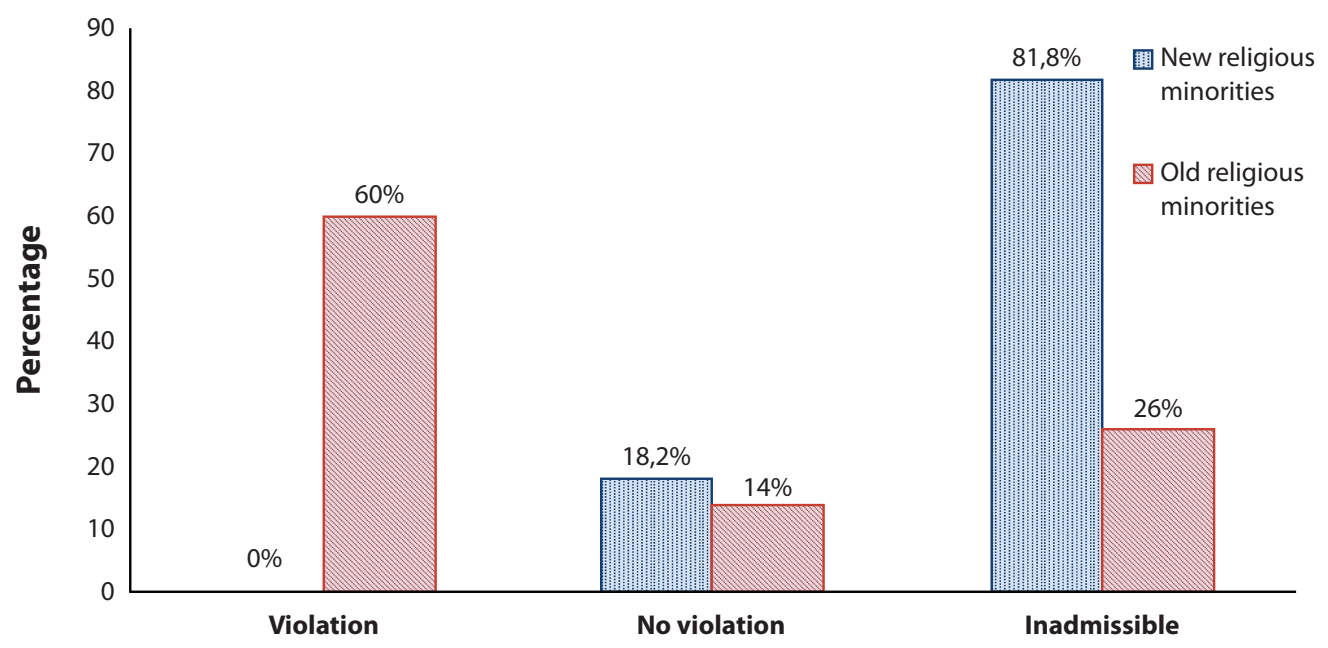

Table 2 Percentages of violations, no violations and inadmissibility decisions of the ECtHR and the EComHR regarding old and nem religious minoritie

\begin{tabular}{|l|l|l|l|}
\hline Old and new minorities ECtHR & Violation & No violation & Inadmissible \\
\hline Baptists & $0 \%$ & $0 \%$ & $100 \%$ \\
\hline Jehovah's Witnesses & $71.4 \%$ & $14.3 \%$ & $14.3 \%$ \\
\hline Jews & $22.2 \%$ & $22.2 \%$ & $55.6 \%$ \\
\hline Muslims & $80 \%$ & $10 \%$ & $10 \%$ \\
\hline Total old minorities & $60 \%$ & $14 \%$ & $26 \%$ \\
\hline Total new minorities & $0 \%$ & $18.2 \%$ & $81.8 \%$ \\
\hline
\end{tabular}

was found and 73.3 per cent of the complaints were not examined on the merits, because they were declared inadmissible (Table 2).

Therefore, the percentages regarding complaints brought by Jehovah's Witnesses and old Muslim minorities support the initial impression of an incoherent approach in the ECtHR's interpretation of Article 9 ECHR in the context of old and new religious minorities. Comparing these abstract percentages to new Muslim or Sikh minorities would thus sustain the assumption that the ECtHR applies the relevant guarantees differently to old religious minorities' complaints than to those of new religious minorities.

Yet, the cases regarding Baptists paint an entirely different picture: All three complaints were declared manifestly ill-founded, which amounts to the largest percentage of inadmissibility decisions, namely 100 per cent. Also, the percentages calculated for complaints brought by members of the Jewish community give the impression, that the right to manifest religious beliefs has been interpreted in a restrictive fashion: Out of nine complaints, five were declared inadmissible. This amounts to half of the total number of inadmissibility decisions taken regarding old religious minorities. Only in two cases, that is 22.2 per cent, the ECtHR found a violation, of which one was a chamber decision that was later overturned by the Grand Chamber. ${ }^{70}$ The cases regarding Baptists and Jews would thus rather serve as an argument against double standards. Considering the mixed conclusions drawn from an analysis of the percentages for individual groups, the next part examines the facts of the cases behind the numbers and tries to justify the numerical differences.

\subsection{An Attempt to Explain the Numerical Differences}

Research has revealed a general tendency of the ECtHR for weaker protection of manifestations of religious beliefs outside the sphere of the religious community and the private home, i.e. in the public sphere. ${ }^{71}$ The ECtHR appears thus to be more cautious in interfering with States' discretion in such cases. By means of a comparison of the aspects of the right to freedom of religion as well as the factual circumstances at issue in the cases included in the above-presented numerical analyses, this conceptual distinction between the public and private sphere has been identified as one of many poten-

70. Cha'are Shalom Ve Tsedek v. France [GC], ECHR 2000-VII 195.

71. See J. Ringelheim, 'Rights, Religion and the Public Sphere: The European Court of Human Rights in Search of a Theory?', in L. Zucca and C. Ungureanu (eds.), Law, State and Religion in the New Europe: Debates and Dilemmas (2012), at 283. 
tial reasons for the differences discovered. ${ }^{72}$ Consequently, the rest of this article will focus its attention on the potentialities of the distinction between the public and private sphere to explain the revealed numerical differences.

\subsubsection{The Public and Private Distinction as a Rule}

Taking a closer look at the nine cases brought by old Muslim minorities, all the cases in which a violation was found concerned individuals, who wanted to manifest their religious belief within a religious community. In a case concerning Moldova, for example, the ECtHR found that the dispersal of a private religious ceremony by the police and the subsequent prosecution for practicing a non-recognised religion violated the right to freedom of religion. ${ }^{73}$ Many cases were also brought against public interference with the organisational structure of a religious community. In a case, in which the Grand Chamber of the ECtHR found a violation of Article $9 \mathrm{ECHR}$, for instance, Bulgaria had refused to register an elected leader of the Muslim religious community, and instead replaced him with a leadership chosen by the State. ${ }^{74}$

Only the case Kosteski v. Former Yugoslav Republic of Macedonia, concerned a manifestation of religious belief in the public sphere, namely a person who was fined for missing work on a Muslim religious holiday. ${ }^{75}$ Interestingly, this was at the same time the only complaint that came from a member of an old Muslim minority, in which the ECtHR did not find a violation of Article 9 ECHR. Furthermore, this is the only decision comparable to the cases brought by new Muslim minorities, because it also concerns a public manifestation of religious beliefs. In the cases brought by members of new Muslim minorities, which concerned for example the wearing of a headscarf or a burqa in schools or public places, ${ }^{76}$ the applicants confronted other people with their religious beliefs and requested tolerance and accommodation of their religious manifestations instead of prohibition or exclusion. As already mentioned, the denial of these requests was not seen as a violation of the right to manifest religious beliefs and, contrary to the UNHRC, the ECtHR did not recognise a duty to accommodate or tolerate these religious practices under Article 9 ECHR. ${ }^{77}$ Also in the cases regarding old reli-

72. For an approach focusing on the factor of 'European consensus', see K. Henrard, 'How the European Court of Human Rights' Concern Regarding European Consensus Tempers the Effective Protection of Freedom of Religion', 4(3) Oxford Journal of Law and Religion 398 (2015).

73. Masaev v. Moldova, App. no. 6303/05 (ECHR, 12 May 2009).

74. Hasan and Chaush v. Bulgaria [GC], ECHR 2000-XI 117.

75. Kosteski v. Former Yugoslav Republic of Macedonia, App. no. 55170/00 (ECHR, 13 April 2006).

76. See, for example, ECtHR Aktas v. France, above n. 8.

77. For a broader account of this issue, see K. Henrard, 'Duties of Reasonable Accommodation in Relation to Religion and the European Court of Human Rights: A Closer Look at the Prohibition of Discrimination, the Freedom of Religion and Related Duties of State Neutrality', 5(1) Erasmus Law Review 59 (2012); Henrard (2012), above n. 61; contrary to the ECtHR, the CoE Parliamentary Assembly has called on Member States to promote reasonable accommodation as 'a pragmatic means of ensuring the effective and full enjoyment of freedom of religion' (Res 2036 (2015), at para. 2). gious minorities' manifestations of religious beliefs in the public sphere, the ECtHR found very few to no violations. The ECtHR for example did not conclude for a duty of the State to change the dates of court proceedings when they coincide with Jewish holidays. ${ }^{78}$ Also a complaint brought by an adherent of the Baptist Church requesting exemption from sexual education class was not even examined on the merits, but declared inadmissible. $^{79}$

When looking at this presentation of case law, it seems thus that the basic assumption that the ECtHR offers a weaker protection to religious manifestations in the public sphere might be able to explain the significant difference in the percentages of violations, no violations and inadmissibility decisions among the different minority groups. ${ }^{80}$ Although this approach can be questioned, it does in principle not indicate double standards if applied consistently. Yet, one particularly interesting exception in the ECtHR's restrictive approach to old and new religious minorities' manifestations of religious belief in the public sphere can be identified among the cases included in the conducted empirical research: Exemptions for Jehovah's Witnesses from military service.

\subsubsection{The Exception to the Rule: Jehovah's Witnesses' Objection to Military Service}

Although the issue of conscientious objection to military service by Jehovah's Witnesses ${ }^{81}$ clearly concerns the public sphere, the ECtHR decided that States have an obligation to accommodate these beliefs by exempting Jehovah's Witnesses from military service in order to respect their religious beliefs. ${ }^{82}$ Taking a closer look at this issue, it appears striking to see that the approach of the ECtHR, respectively the EComHR, was initially in contradiction with the UNHRC.

As early as 1966, the EComHR was confronted with a complaint of a Jehovah's Witness alleging a violation of Article 9 ECHR due to the refusal of German authori-

78. See S. H. and H. V. v. Austria, App. no. 18960/91 (EComHR, 13 January 1993); Sessa v. Italy, ECHR 2012149 (extracts).

79. Dojan and others v. Germany, App. nos. 319/08, 2455/08 and 7908/10 (ECHR, 13 September 2011).

80. This restrictive interpretation can also be linked with the different understanding of the concept of secularism developed by the UNHRC and the ECtHR; see A. Barras, 'Transnational Understandings of Secularisms and Their Impact on the Right to Religious Freedom - Exploring Religious Symbols Cases at the UN and ECHR', 11(2) Journal of Human Rights 263, at $265 \mathrm{ff}$. (2012).

81. It needs to be noted that various religious minority groups brought complaints regarding conscientious objection to military service; see, for a detailed overview, H. Takemura, International Human Right to Conscientious Objection to Military Service and Individual Duties to Disobey Manifestly Illegal Orders (2009), in particular at $19 \mathrm{ff}$. This article focuses however on cases brought by Jehovah's Witnesses due to the reasons specified in Section 2.2 .

82. Bayatyan v. Armenia [GC], ECHR 2011-IV 1; see P. Muzny, 'Bayatyan v Armenia: The Grand Chamber Renders a Grand Judgment', 12(1) Human Rights Law Review 135 (2012). 
ties to exempt him from military service. ${ }^{83}$ The EComHR did not find a violation of the applicant's right to freedom of religion. It based its argumentation on Article 4(3b) ECHR, which states that the term prohibition of forced and compulsory labour shall not include 'any service of a military character or, in case of conscientious objectors in countries where they are recognised, service exacted instead of compulsory military service'. According to the interpretation of the EComHR, Article 9 ECHR was therefore not applicable to conscientious objectors. Hence, the complaint was declared manifestly ill-founded and thus inadmissible. Like the question of the interpretation of new religious minorities' religious manifestations in the public sphere, the exemption from military service was a controversial issue at the time, which was seen to be best left to the discretion of Member States. ${ }^{84}$

While the EComHR confirmed this approach in subsequent decisions, not only concerning Jehovah's Witnesses, ${ }^{85}$ the ECtHR avoided touching upon the issue. This can be seen in a complaint brought by two religious ministers of the Central Congregation of the Christian Jehovah's Witnesses of Greece, ${ }^{86}$ which the ECtHR only examined under Article 5 ECHR and declared that the detention of the applicants based on their refusal to perform military service was not lawful. It was, however, not seen as necessary to examine the complaint under Article 9 ECHR.

While at first following the EComHR's approach to conscientious objection to military service in two cases concerning objection based on ethical grounds, ${ }^{87}$ the UNHRC recognised a right to conscientious objection first in an obiter dictum in a recommendation in the framework of the individual complaint procedure in $1991^{88}$ and then, more clearly, in its General Comment No. 22 in $1993 .{ }^{89}$ This was subsequently confirmed in the first individual complaint brought by a Jehovah's Witness to the UNHRC against the Republic of Korea in $2006 .{ }^{90}$ It appears interesting to highlight that Article 8(3) ICCPR excludes military and civil service from the scope of the prohibition of forced labour with the exact same wording as Article 4(3b) ECHR. The UNHRC's revision of the interpretation of this provision led thus

83. Grandrath v. Germany, App. no. 2299/64 (ECHR, 12 December 1966). It is worth noting that the applicant in question did not only object to performing military service, but also to substitute civil service; nevertheless, the EComHR's reasoning clearly also includes exemption from military service alone.

84. See Muzny, above n. 82

85. See, for example, X. v. Germany (1977), 9 DR 201; Heudens v. Belgium, App. no. 24630/94 (ECHR, 22 May 1995).

86. Tsirlis and Kouloumpas v. Greece, above n. 36.

87. UNHRC Muhonen v. Finland, UN Doc. A/40/40, 8 April 1985; see also UNHRC L.T.K. v. Finland, UN Doc. CCPR/C/OP/2, 9 July 1985

88. UNHRC J.P. v. Canada, UN Doc. A/47/40, 7 November 1991, at para. 4.2.

89. UNHRC, 'General Comment 22 on Article 18 ICCPR', UN Doc. CCPR/C/21/Rev.1/Add.4, 27 September 1993, at para 11. See for further details, in particular the drafting history, Takemura, above n. 81, at $56 \mathrm{ff}$.

90. UNHRC Yeo-Bum Yoon and Myung-Jin Choi v. Republic of Korea, UN Doc. CCPR/C/88/D/1321-1322/2004, 13 November 2006; see also Takemura, above n. 81 , at $70 \mathrm{ff}$. to a direct contradiction with the ECtHR's standing case law at that time, as according to the UNHRC, the provision was neither intended to 'recognize[s] nor exclude[s] a right of conscientious objection'. ${ }^{91}$ The UNHRC then arrived at the conclusion that the Republic of Korea had to foresee a procedure for the recognition of conscientious objections against military service. $^{92}$

In 2011, the Grand Chamber of the ECtHR overturned the long-standing, settled case law in the case Bayatyan v. Armenia. ${ }^{93}$ It arrived at this conclusion based on three main arguments, which are worth highlighting: First, it voiced doubts that the interpretation given to Article 4(3b) ECHR by the EComHR 'reflects the true purpose and meaning of this provision', ${ }^{94}$ as according to the travaux préparatoires the provision was not intended to have a delimiting effect on the guarantees of Article 9 ECHR. ${ }^{95}$ This shows the importance the ECtHR attached in this case to the interpretation based on the object and purpose of the ECHR, which might be inspired by the UNHRC's reasoning in the respective decisions. ${ }^{96}$

Second, the ECtHR referred to important developments on the national and international level since the last decision taken by the EComHR in this regard. ${ }^{97}$ It specifically mentioned the practice of the $\mathrm{UNHRC}^{98}$ and stated that in defining the meaning of terms and notions in the text of the Convention, the Court can and must take into account elements of international law other than the Convention and the interpretation of such elements by competent organs' ${ }^{99}$ Considering that in its decision the ECtHR then followed the approach taken by the UNHRC, this is a strong statement for the coherence of human rights interpretation.

Third, the ECtHR clearly recognised Jehovah's Witnesses as a religious minority whose religious freedom needs to be respected in order to achieve religious harmony and tolerance in society. It stated that 'providing [Jehovah's Witnesses] with the opportunity to serve society as dictated by their conscience might, far from creating unjust inequalities or discrimination as claimed by the Government, rather ensure cohesive and stable plu-

91. UNHRC, General Comment 22, above n. 89, at para. 8.2

92. This approach was confirmed in subsequent decisions regarding the Republic of Korea, Turkey and Turkmenistan; see, for example, the most recent decision UNHRC Sunnet Japparow v. Turkmenistan, UN Doc. CCPR/C/115/D/2223/2012, 29 October 2015.

93. ECtHR Bayatyan v. Armenia [GC], above n. 82; the Chamber decision did not find a violation: Bayatyan v. Armenia, App. no. 23459/03 (ECHR, 27 October 2009); see, for a critique of the Chamber decision the Dissenting Opinion of Judge Power as well as Muzny, above n. 82, at $138 \mathrm{ff}$.

94. ECtHR Bayatyan v. Armenia [GC], above n. 82, at para. 100.

95. See also Muzny, above n. 82 , at 141

96. See also M. Burbergs, 'Recognizing the Right to Conscientious Objection - Part I - Correcting a Mistake', Strasbourg Observers (20 July 2011); available at: <https://strasbourgobservers.com/2011/07/20/ recognizing-the-right-to-conscientious-objection- $\%$ E2 \% $80 \% 93$-part-i\%E2\% $80 \% 93$-correcting-a-mistake/>.

97. See, concerning the role played by the concept of European consensus in this decision, Henrard (2012), above n. 61, at 975.

98. ECtHR Bayatyan v. Armenia [GC], above n. 82, at para. 105.

99. Ibid., at para. 102. 
ralism and promote religious harmony and tolerance in society'. 100

\section{Conclusion}

The example of the exemption from military service for Jehovah's Witnesses (and others) shows that the interpretation of human rights is not set in stone, but evolves with time. ${ }^{101}$ In the case of Bayatyan v. Armenia, this change was in particular motivated by the need to protect Jehovah's Witnesses as a religious minority and to respect 'pluralism, tolerance and broadmindedness [as the] hallmarks of a "democratic society". 102 In this sense, respect towards and accommodation of the beliefs of a minority religious group was seen as ensuring 'cohesive and stable pluralism and promot[ing] religious harmony and tolerance in society'. ${ }^{103}$ Such principles can already be found in the preambles of the international human rights instruments, which pursue the aim to establish justice and peace in the world. ${ }^{104}$

Applied to the interpretation of new minorities' right to manifest their religious beliefs, it can be stated that the case law of the ECtHR is not in line with these common guiding principles: ${ }^{105}$ Instead of promoting pluralism and tolerance, the right to religious freedom of those groups is restricted in the name of social unity. Yet, experience shows that restricting the religious liberty of a large number of citizens does not lead to religious harmony and peace, but rather to exclusion and social conflict. ${ }^{106}$ Also, the political theorist Iris Marion Young stated that 'reduc[ing] the differently similar to the same [...] turns the merely different into the absolutely other [and] inevitably generates dichotomy instead of unity'. ${ }^{107}$ Such concerns for respect of the basic principles of pluralism and tolerance seem to be attributed stronger weight in the decisions of the UNHRC regarding new minorities' right to freedom of religion, which thus rightly refused to follow the ECtHR's approach in this regard.

Could the UNHRC thus, not only for coherence's sake, serve as a role model for the ECtHR (again)? Recent decisions of the ECtHR in the area of religious freedom

100. Ibid., at para. 126 (emphasis added).

101. In this regard, it is important to mention that the ECtHR, since a long time, regards the ECHR as a living instrument subject to dynamic interpretation; see already ECtHR Tyrer v. the United Kingdom, App. no. 5856/72 (ECHR, 25 April 1978), at para. 31.

102. ECtHR Bayatyan v Armenia [GC], above n. 82, at para. 126.

103. Ibid.

104. ECHR preamble; ICCPR preamble.

105. See also S.E. Berry, 'A Tale of Two Instruments: Religious Minorities and the Council of Europe's Rights Regime', 30 Netherlands Quarterly of Human Rights 10 (2012); K. Henrard, The Ambiguous Relationship between Religious Minorities and Fundamental (Minority) Rights (2011), at $53 \mathrm{ff}$

106. C. Wellmann, 'Religious Human Rights and Peace', 11 Journal of Human Rights 210, at 215 (2012); E. Craig, 'From Security to Justice? The Development of a More Justice-Oriented Approach to the Realisation of European Minority Rights Standards', 30 Netherlands Quarterly of Human Rights 40 (2012)

107. I. Young, Justice and the Politics of Difference (1990), at 99 seem to show at least some signs of a less restrictive approach to the right to freedom of religion also in the public sphere. ${ }^{108}$ As an example from the cases included in the conducted empirical research, the judgment Karaahmed v. Bulgaria ${ }^{109}$ can be mentioned, which concerned a violent clash in front of a mosque between members of a nationalist party and Muslim worshippers. The members of the Muslim community in the mosque in question belonged to the old Muslim minority in Bulgaria, but also came from immigration countries such as Turkey. Although the party stated as its primary motivation the allegedly disturbing call for prayers coming from the mosque in question, the statements and actions of the party's members showed that they were in fact moved by racial and religious intolerance towards Turkish immigrants. The ECtHR found that Bulgarian authorities had violated their positive obligations flowing from Article 9 ECHR, as they did not 'strike a proper balance in the steps they took to ensure the effective and peaceful exercise of the rights of the demonstrators and the rights of the [...] worshippers to pray together' 110

Other cases, however, paint a rather mixed picture. One can think for example of the cases Ebrahimian v. France, ${ }^{111}$ in which the ECtHR found that the wearing of a headscarf was a legitimate reason for the nonrenewal of the employment contract of a nurse in a public hospital, or the most recent case Osmano $\breve{g} l u$ and Kocabaş v. Smitzerland, ${ }^{112}$ where the refusal to grant Muslim students exemption from mixed-sex swimming classes was not seen as amounting to a violation of their right to manifest their religious beliefs. Lastly, also S.A.S. v. France, ${ }^{113}$ in which the Grand Chamber of the ECtHR found that the prohibition to wear a burqa in public places did not violate Article 9 ECHR, has to be mentioned. The latter decision even led to a division within the Council of Europe: The CoE Commissioner for Human Rights, for example, had stated before that a general burqa ban would raise serious questions concerning its compatibility with the ECHR because it would lead to 'further exclusion and alienation in European societies'. ${ }^{114}$

Yet, from a more optimistic perspective one can establish that these decisions at least involved an examination on the merits, as opposed to earlier complaints, which had been declared manifestly ill-founded and thus inad-

108. Consider, for example, the cases Eweida and others v. the United Kingdom, ECHR 2013-I 215 (extracts); Vartic (No 2) v. Romania, App. no. 14150/08 (ECHR, 17 December 2013); see also the analysis of Henrard (2012), above n. 61

109. Karaahmed v. Bulgaria, App. no. 30587/13 (ECHR, 24 February 2015).

110. Ibid., at para. 111.

111. ECtHR Ebrahimian v. France, above n. 47.

112. Osmanoğ/u and Kocabaş v. Switzerland, App. no. 29086/12 (ECHR, 10 January 2017)

113. ECtHR S.A.S. v. France [GC], above n. 47

114. T. Hammarberg, Human Rights in Europe: No Grounds for Complacency (2011), at 39; see, furthermore, CoE Parliamentary Assembly, Res. 1743 (2010), at para. 16 and Rec. 1927 (2010), at para. 3.13 
missible. ${ }^{115}$ This might be a sign that the ECtHR is taking the difficulties, which new religious minorities are encountering in realising their human right to manifest their religious beliefs, more seriously and is slowly reconsidering its approach.

115. See, for the importance of sufficient reasoning and the problematic declaration as manifestly ill-founded, Gerards, above n. 53, at 154 ff.; Brems and Lavrysen (2013), above n. 67, at $180 \mathrm{ff}$. 